\title{
Predikant en politiek ${ }^{1}$
}

\author{
J.H. van Wyk \\ Departement Dogmatologiese Vakke \\ HTS/PU vir CHO \\ POTCHEFSTROOM
}

\begin{abstract}
In this article different perspectives are given on the issue that a Christian minister can be - and should be - involved in politics. Pictism and quietism are forcign to a Reformational approach, although politicism as monted by the Theologv of Revolution is also unacceptable. The question is not whether a minister should engage in politics but how. In this connection the author attempts to provide a few guidelines for a politics of the kingdom of God.
\end{abstract}

\section{INLEIDING}

Wanneer oor die boeiende en omstrede tema van 'predikant en politiek' gehandel word, is dit vir 'n goeie verstaan noodsaaklik om enkele terme kortliks te omskryf Onder politiek verstaan ek breedweg die inrigting van die staatshuishouding. Politiek is dus ' $n$ meer omvattende term as partypolitiek, wat daarvan'n deel uitmaak. Dit behels myns insiens ook veel meer as die bekende definisie van 'die kuns van die moontlike'; dit is veral ook 'die kuns van die behoorlike', aangesien politiek en moraliteit nooit van mekaar losgemaak mag word nie. Daar is weinig dinge so immoreel as immorele politiek. Verder moet ons ook onderskei tussen 'n politikus en 'n politikoloog; eersgenoemde hou hom veral besig met die praktiese politiek van die huidige tyd, laasgenoemde met ' $n$ wetenskaplike besinning oor die politiek. ' $n$ Politikus mag hom egter nie aan die politikologie onttrek nie want dan verval hy in blote pragmatisme.

Die taak van 'n predikant weer word gewoonlik omskryf as verbi Divini minister; hy staan in diens van God en hy bedien die Woord van God in die gemeente en aan die wêreld. Die vraag hoe hierdie God lyk en hoe die Woord van God daar uitsien, bepaal die aard van sy diens. Daaroor weldra meer.

Die invalshoek van hierdie artikel is nie die vraag of 'n predikant polities betrokke mag wees nie maar die stelling dat hy inderdaad polities betrokke moét wees en eintlik nie anders kán wees nie. Die vraag is nie ơf hy betrokke moet wees nie maar hóé. Die vraag gaan dus oor die árd van sy betrokkenheid.

1 Oorspronklik aangebied as voordrag voor die GTV, Pretoria - 10 Februarie 1992. 


\section{WAAROM IS 'N PREDIKANT POLTTIES BETROKKE ?}

Hierdie aspek word vanuit 'n paar bekende reformatoriese gesigspunte benader, naamlik vanuit die soewereiniteit van God, die universaliteit van die Woord, die profetiese roeping van die kerk, die unisiteit van die lewe en die realiteit van die koninkryk. Hierdie feit kan ook anders geformuleer word deur te sê dat hierdie aspek behandel word vanuit die Godsleer (Christologie), die Skrifleer, die ekklesiologie, die etiek en die eskatologie.

\subsection{Die soewereiniteit van God}

Vroeër is opgemerk dat die taak van die predikant omskryf kan word as verbi Divini minister; dus is die vraag na die Godsleer hier van fundamentele betekenis. Hoe lyk die God wie se Woord predikante bedien? Is dit 'n lewende of dooie god, 'n stamgod of universele God, 'n onmagtige of soewereine God? Is dit 'n God wat belangstel in die 'siel' van mense of ook in hulle liggame? Is dit 'n God wat net in die hemel heers of ook op die aarde? Is dit 'n God wat net in die kerk geëer moet word of moet Hy ook in die politiek gedien word? Hoe het hierdie God Homself in sy Woord geopenbaar?

Uit die Ou Testament is dit baie duidelik dat hierdie God geen stamgod van Israel is nie maar die God van die nasies wie se heerskappy oor die ganse aarde erken en bely moet word. Voortdurend word daar in die Ou Testament gewys op die onmag van die afgode en die almag van die ware God. Hierdie God wil nie net in die kultusdiens gedien wees nie maar ook in die politiek; nie net in die tempel nie maar ook in die samelewing; nie net met offers nie maar ook met 'n regte lewe.

In die Nuwe Testament neem hierdie Godsregering 'n besondere dimensie aan in die lewe en werk van Jesus Christus. Nou regeer God deur Christus (Matt. 28:18; 1 Kor. 15:24; HK 19:50) sodat die Godsregering die gestalte van 'n Christusregering aanneem. Vandaar ook die ontsaglike stryd in die Vroeë Kerk: Is Jesus Christus die Here of is die keiser die Here? Vandaar dat een van die heel vroegste belydenisse in die Vroeë Kerk gelui het: "Jesus is die Here" (Rom. 10:9; I Kor. 12:3)! Christus is die Baas, nié net oor die kerk nie maar ook oor die kosmos; Hy is die triomfator oor alle bose magte (Ef.; Kol.).

Daarom, omdat God Hom só in die Skrif geopenbaar het as die God wat oor alles en oor almal regeer, oor die hemel en oor die aarde, oor die siel en oor die liggaam, oor die kerk en oor die politiek, dárom kan sy dienaars nie anders nie as om Hom $60 \mathrm{k}$ in die politiek te dien. Indien hulle dit nie doen nie, loën hulle die soewereiniteit van God en die koningskap van Jesus Christus. Geen duimbreedte van die samelewing mag aan die heerskappy van Christus onttrek word nie, het A. Kuyper tereg opgemerk! Daar is geen terrein op aarde só soewerein of Christus het ook daaroor seggenskap 
nie.

\section{Die universaliteit van die Woord}

Karakteristiek van die predikant se werk, het ons gesê, is die aspek van die bediening van die Woord van God (verbi Divini minister). Die vraag is dus onmiddellik ter sake hoe hierdie Woord daar uitsien. Is dit 'n Woord - 'n evangelie - wat net daarvoor bedoel is om ' $n$ siel in die hemel te kry of is dit ' $n$ Woord wat ook politieke betekenis het? Is dit 'n Woord wat net vir individue geld of geld dit ook vir samelewings en samelewingstrukture? Is dit 'n Woord wat net van die hemel vertel of besit dit ook betekenis vir die lewe op aarde? Is dit 'n Woord wat net melding maak van die mens se verhouding tot God of het dit ook iets te sê vir die mens se verhouding tot die medemens en selfs vir die mens se verhouding tot die natur? Hoe dien hierdie Woord homself aan?

Wanneer hierdie Woord noukeurig ondersoek word, is dit gou duidelik dat dit met 'n universele aanspraak kom: dit wil lig bied (Ps. 119:105); nie net vir die siel nie maar ook vir die liggaam; nie net vir individue nie maar ook vir samelewings; nie net vir die kerk nie maar ook vir die politiek, ja, vir die ganse lewe.

Natuurlik moet hier onderskei word tussen die feit dát die Bybel lig gee vir die volle lewe en die vraag hóé dit daarvoor lig gee. Bekend, en korrek, is die uitspraak dat ons die Bybel nie as wetenskaplike handboek vir die politiek/politikologie mag gebruik nie, dit wil sê as 'n teksboek wat alle ou en moderne politieke vrae direk beantwoord. Die Bybel moet reg verstaan en juis vertolk word. Ons kan nie sommer een-twee-drie vanuit die Ou-Testamentiese teokrasie oorspring na 'n teokrasie vir Suid-Afrika met sy plurale samelewing nie. Ons teokrasie is vandag veel eerder 'n geloofsbelydenis: ons glo en bely dat God deur Christus alles regeer, selfs al lyk dit nie altyd so nie (Heb. 2:8). Die Bybel bied aan ons die groot beginsels vir die politiek, soos byvoorbeeld vrede en versoening, vryheid en verantwoordelikheid, ordelikheid en regverdigheid, naasteliefde en medemenslikheid. Hierdie beginsels, wat nie geignoreer mag word nie, vra om 'n konkrete toepassing in elke besondere situasie. Vanselfsprekend sal niemand ontken dat hierdie beginsels in die politiek 'n baie voorlopige gestalte aanneem en dat daar in die kerk, teoreties altans, veel groter ruimte is om dit te realiseer nie. Die Bybel vra egter nie net vir vrede in die kerk nie maar ook vir vrede búíte die kerk (Rom. 12:18).

'n Predikant bedien die Woord, die universele Woord, en hy kan nie daaraan ontkom nie dat hierdie Woord ook vir die politiek lig bied. Indien 'n predikant sou ontken dat die Woord politieke relevansie besit, ontkrag hy die Woord en doen hy afbreuk aan die reformatoriese beginsel van die sola Scriptura. 
"In U lig sien ons die lig" (Ps. 36:10) - nie net in die wetenskap nie maar ook in die politiek.

\subsection{Die profetiese roeping van die kerk}

Christus gee aan sy navolgers die opdrag om die "sout vir die aarde" en die "lig vir die wêreld" te wees (Matt. 5:13-16). Dit impliseer dat hulle ook die sout vir die politieke aarde en die lig vir die politieke wêreld sal wees. Die kerk het kragtens artikel 28 van die Kerkorde 'n onnalaatbare profetiese roeping in en teenoor die wêreld.

In hierdie verband het die ekklesiologie van A. Kuyper, gekombineer met 'n eensydige verstaan van artikel 30 van die Kerkorde, 'n verlammende uitwerking op gereformeerde kerke wêreldwyd gehad. Kuyper, met sy dualistiese kerkbeskouing, het geoordeel dat die kerk as instituut geen profetiese roeping na buite het nie en dat hierdie roeping na buite tot die terrein van die kerk-as-organisme (die sg. Christelike organisasie) behoort. Inderdaad vind ons by Kuyper feitlik niks oor die profetiese roeping van die kerk (as instituut) nie. Voeg hierby die eensydige verstaan van 'kerklike sake' in artikel 30 van die Kerkorde en die deur is wyd oop om totaal af te sien van die profetiese roeping van die kerk in die samelewing.

Die vraag is nie of die kerk 'n profetiese roeping het nie maar hó hy dit moet uitoefen. In hierdie verband het A. Troost tereg daarop gewys dat ons eerder moet praat van die kérklike verantwoordelikheid ten opsigte van die politiek as van die politieke verantwoordelikheid van die kerk. Die kerk moet sy roeping na buite soos 'n kérk nakom en nie soos 'n politieke party nie. Hy moet waak teen verpolitisering maar ook teen piëtisering en kwiëtisering. Tereg het Sinode Potchefstroom soos volg besluit:

In die verkondiging van die Woord behoort die kerk - waaraan die boodskap van Christus se koninkryk toevertrou is - moedig en toepaslik oor heersende vraagstukke te praat, sowel tot opbouing en vermaning van sy lede as, waar nodig, tot kritiek op die optrede en beleid van owerheid en organisasies (Acta, 1970:63).

In die uitoefening van die profetiese roeping van die kerk neem die predikant, as verbi Divini minister, geen onbelangrike plek in nie.

\section{Die unisiteit van die lewe}

Die Christelike lewe vertoon 'n eenheid en hierdie eenheid kan alleen op uiters kunsmatige wyse in verskillende waterdigte kompartemente afgesluit word. Sonder twyfel is daar verskillende dimensies in die lewe en het die lewe 'n kerklike en politieke kant. 'n morele en juridiese aspek, maar hierdie dimensies mag nooit 'n selfstandige bestaan voer nie. Elke Christen leef coram Deo, één lewe voor die aangesig van God. Dis onhoudbaar om 'n dubbellewe te voer, een (sakrale) lewe in die 
kerk en 'n ander (sekulêre) lewe in die politiek. Wel praat die Bybel van 'n dubbele lewe maar dan neem hierdie dubbele lewe heeltemal ander kontoere aan. Die dubbele lewe waarvan die Bybel praat, is nie dié tussen kerk en politiek nie maar dié tussen die mens se ou natuur en die mens se nuwe natuur, die dubbellewe tussen vleesmens en Gees-mens. En hiérdie tweeslagtigheid openbaar hom in sowel die mens se kerlike as politieke lewe!

Dit is prakties en prinsipieel onmoontlik vir die predikant om hom aan die politiek te onttrek. As hy dit doen, leef hy 'n halwe lewe, want die lewe vorm 'n onlosmaaklike eenheid. Hierdie waarheid word voortreflik in die Afrika-mensbeskouing voorgestaan en dit kan as gesonde kritiek dien teen die versnipperde en rasionalistiese Westerse mens- en lewensbeskouing.

\subsection{Die realiteit van die koninkryk}

Die koms van die koninkryk van God na hierdie wêreld het 'n enorme politieke relevansie. Ons moet Matteus, wat van die koninkryk van die "hemel" praat, nie verkeerd verstaan nie, en so ook nie die uitspraak in Johannes (18:36) dat Christus se koninkryk "nie van hierdie wêreld" is nie. Dit is bekend dat Matteus ter wille van sy JoodsChristelike lesers die Godsnaam vermy en eerder van "koninkryk van die hemel" as van "koninkryk van God" praat, maar inhoudelik beteken dit presies dieselfde. Hy wil hoegenaamd nie sê dat die koninkryk nie (ook) vir die aarde bedoel is nie. En Johan nes 18 moet ook nie verkeerd verstaan word nie asof Christus na 'n buite-wêreldlike koninkryk verwys het nie. Nee, Hy bedoel dat sy koninkryk nie vanuit die aarde op menslike wyse en met menslike middele (geweld!) omhoog groei nie maar (in finale instansie altans) 'n geskenk van God is. Dis 'n wêreldlike maar nie 'n wêreldse koninkryk nie.

Die koninkyk van God gee konkreet daaraan uitdrukking dat God oor alles regeer en dat almal aan daardie koninkryk diensbaar moet wees. Waar aardse koninkryke weier om aan die Godsryk diensbaar te wees, vorm hierdie ryk hoe langer hoe meer 'n bedreiging vir daardie aardse ryke (vgl. Dan. 2:44; Joh.11:48).

'n Predikant moet besef dat hy nie net in diens staan van die gemeente nie maar dat hy voor alles in diens staan van God én daarom van die koninkryk van God. Ook in die politiek moet iets deurskemer en iets reflekteer van die beginsels van die koninkryk, sodat ons politiek 'n politiek van hoop en nie van wanhoop sal wees nie. Om die koninkryk van God "eerste" te soek (Matt. 6:33), beteken nie om die koninkryk náás die politiek eerste te soek nie mar om die koninkryk in die politiek eerste te soek. Verantwoorde politiek is koninkrykspolitiek, dit wil sè, geskoei op die lees van die beginsels van die koninkryk van God. 
'n Volgende vraag is hóé 'n predikant polities betrokke kan en mag wees? 'n Aantal moontlikhede sal hier krities oorweeg word.

\section{HOE IS DIE PREDIKANT POLTIIES BETROKKE?}

\subsection{Die piētistiese benadering}

In hierdie, tipies privatistiese, benadering word uitgegaan van die gedagte dat 'godsdiens 'n privaatsaak' is en dat dit niks met politiek te make het nie. Die predikant moet hom besig hou met 'sy eie werk' en 'die politiek aan die politici oorlaat'. Vir sover 'n politikus ook 'n Christen is, mag sy godsdiens nie met sy politiek 'inmeng' nie.

Hierdie standpunt kom dikwels voor en word byvoorbeeld aangetref by twee groot Duitse piëtistiese teoloë soos Adolf von Harnack en Rudolf Bultmann. In Suid-Afrika kom die teologiese beskouings van die bekende Andrew Murray al hoe meer onder kritiek vanweë sy piëtistiese en apolitieke ingesteldheid waardeur hy juis die weg vir die politieke teologie van apartheid oopgemaak het.

Tans vind hierdie standpunt ook 'n sterk voorstander in mnr. Nelson Mandela.

Hierdie benadering is egter in die lig van wat reeds gesê is, volkome onhoudbaar.

\section{Die kwiëtistiese benadering}

In 'n kwiëtistiese benadering tot die politiek, 'n benadering wat met die vorige standpunt groot ooreenkoms vertoon, word van die gedagte uitgegaan dat iemand hom vryblywend en neutraal moet hou en hom nie met die politiek moet inmeng nie. Die kerk en die predikant moet swyg.

Die probleem met hierdie standpunt is egter dat swye ook ' $n$ manier van praat is. Swye kan soms afkeuring impliseer inhou (vgl. Mark. 15:5; Luk. 23:9), maar dit kan ook as ondersteuning vertolk word. Trouens, meesal word swye as ondersteuning van die status quo vertolk, sodat die swyende predikant as status quo predikant gesien word.

Soos die vorige is ook hierdie standpunt onaanvaarbaar. Dit is immers onmoontlik vir 'n predikant om, met die Bybel in die hand, te swyg wanneer die politiek van sy tyd goddelose en onmenslike afmetings aanneem; dis onmoontlik om neutraal te wees indien onreg seëvier en chaos oorneem; dis onmoontlik om die status quo kritiekloos te aanvaar as arm mense verdruk en rykes korrup voortlewe. In hierdie verband kan veral gedink word aan die verset van K. Schilder, D. Bonhoeffer en K. Barth teen die Nazisme. 


\subsection{Die politisistiese benadering}

Teenoor bogenoemde twee benaderingswyses staan die politisistiese benadering met sy radikale en aktivistiese ingesteldheid. Hier geld inderdaad die waarskuwing van H.M. Kuitert dat "alles politiek is maar politiek is nie alles nie". Inderdaad mag 'n predikant nie sy bediening verpolitiseer nie al het sy bediening 'n onnalaatbare politieke dimensie. ' $n$ Predikant is nie 'n praktiese politikus nie, al begelei hy die politiek van sy tyd krities vanuit die Woord.

Hierdie benadering is sterk in die Swart Teologie en Wit Teologie verteenwoordig en 'n moderne eksponent daarvan is te vind in Canaan Banana - veel meer as in Allan Boesak en Desmond Tutu. Ons moet ook nie dink dat Gereformeerde teoloë hier vryuit gaan nie. 'n Mens kan slegs sommige artikels wat in die veertigerjare in Die Kerkblad verskyn het, naslaan om te sien hoeveel politiek (apartheid!) daar geskryf is. Hierdie tipe denke vind natuurlik 'n weelderige teelaarde wanneer lidmate polities eenders dink, maar dit kom onder groot spanning wanneer politieke diversiteit hom in die kerk openbaar.

'n Aktivisties verpolitiseerde bediening bring egter groot gevare met hom mee: dit identifiseer alte maklik die koninkryk van God met die eie nasionale koninkryk (vgl. Hand. 1:6); dit vereensydig die evangelie van verlossing tot politieke bevryding; dit vereng sonde tot politieke onreg; dit maak van Christus 'n politieke aktivis en van die kerk 'n politieke agitator en dit vergeet dat al ons menslike dade onder die oordeel van God moet deurgaan.

\subsection{Die koninkryksentriese benadering}

Daar bly eintlik net een verantwoorde siening oor en dit is ' $n$ koninkryksentriese benadering; anders gesê, 'n navolging van die politiek van Jesus. Jesus Christus het nie die pad van isolasie opgegaan, soos die Essene van sy tyd gedoen het nie, ook nie die pad van imperialisme (of status quo-isme) nie, soos die Herodiane en Sadduseërs, en ook nie die pad van nasionalisme nie, soos die Fariseërs en Selote, laasgenoemde met ' $n$ rewolusionêre inslag. Christus is al in die tuig van die pasifisme en ook die rewolusionisme geplaas, maar hierdie pogings het nog weinig kere geslaag omdat Hy sy eie weg gegaan en sy eie politiek beoefen het, naamlik die politiek van die koninkryk.

Sou ons dalk iets meer oor die 'politiek van die koninkryk' kon sê? Van al die baie dinge wat hieroor gesê kan word, wil ek graag op twee uiters belangrike aspekte daarvan wys. Eerstens moet opgemerk word dat die koninkryk van God alle aardse koninkryke relativeer en tweedens dat dit alle aardse koninkryke relateer. Wat word hiermee bedoel? 
As ons sê dat die koninkryk van God alle aardse koninkryke relativeer, dan word daarmee bedoel dat die koninkryk van God alle aardse koninkryke betreklik maak omdat alleen die Godsryk onverganklik is; alle menslike koninkryke, ook ons Afrikanerkoninkryk en ons Suid-Afrikaanse koninkryk, is aan verganklikheid onderworpe. Aardse koninkryke kom en gaan en wie sy heil daarvan verwag en sy vertroue daarop stel, verwag en vertrou tevergeefs. Die koninkryk van God bewaar ons van verabsolutering van die koninkryk van die mens. Ons mag immers nie dinge wat aan God toekom aan die keiser gee nie (Matt. 22:21).

Verder het die koninkryk van God ook die besondere kenmerk dat dit aardse koninkryke met homself relateer, dit wil sê, in verhouding tot homself bring. Aardse koninkryke mag nie hulle eie lewe voer los van die koninkryk van God nie, maar hulle moet daaraan diensbaar wees. Hierdie ingesteldheid maak neutralisme en privatisme onmoontlik. Die koninkryk van God oefen voortdurend kritiek uit op ons aardse koninkryke; dit roep voortdurend om 'n politiek van liefde, 'n politiek van geregtigheid, 'n politiek van vryheid, 'n politiek van vrede en 'n politiek van hoop. Die koninkryk van God staan krities teenoor 'n politiek van haat, 'n politiek van onreg, 'n politiek van slawerny, 'n politiek van geweld en 'n politiek van utopie.

Augustinus het in sy groot boek oor die De civitate Dei tereg aandag daarvoor gevra dat alle aardse koninkryke in die lig van die koninkryk van God relatief is, maar hy het nie voldoende daarin geslaag om die verhouding tussen die twee ryke uit te spel nie.

'n Predikant behoort myns insiens hierdie koninkryksentriese politieke benadering na te volg want dit voldoen die beste aan die vereistes in punt 2 neergelê.

'n Volgende vraag wat hom tans na vore dring, is die vraag wáár (en die hóé hang daarmee saam) 'n predikant dan hierdie betrokkenheid moet uitleef.

\section{WAAR IS DIE PREDIKANT POLTTIES BETROKKE?}

Ek wil hier graag twee aspekte belig en eerstens wys op die kerklike betrokkenheid (by die politiek) en tweedens op (direkte) politieke betrokkenheid.

\subsection{Kerklike betrokkenheid}

'n Hele aantal fasette van die bediening van die predikant kan hier die revue passeer.

\subsubsection{Politiek in die gebed}

Daar kan ten eerste gewys word op die faset van politiek in die gebed. Verlede jaar het 'n briefskrywer in Die Hervormer die opmerking gemaak dat 'n luisteraar uit die gebed van die predikant kan aflei aan watter politieke party hy behoort en die vraag is of 
hierdie bewering korrek is. Bid die predikant vir die owerheid? Hóé bid hy vir die owerheid? Bid hy vir die opposisie? Hoe? Bid hy ook vir die vyand? Om vir die owerheid te bid is ' $n$ Bybelse opdrag (1 Tim. 2:2), maar die vraag is waarom dit dikwels so moeilik is om vir 'n politieke opponent voorbidding te doen. Die (familie- en openbare) gebed het ongetwyfeld 'n politieke dimensie en dit kan alleen in ongehoorsaamheid aan die Woord van God nagelaat word. As daar gebid word vir vrede en versoening en vir vryheid en geregtigheid, dan bevat so 'n gebed duidelik 'n politieke dimensie. Iets anders is 'n politieke gebed waar die gebed so gepolitiseer word en so met eie politieke ideale gevul word dat die gebed in 'n politieke monoloog ontaard. Mag daar byvoorbeeld gebid word vir die vál van die regering of sou die Here gevra kon word om vervánging van 'n regering wat onreg handhaaf?

\subsubsection{Politiek en prediking}

Ten tweede kan gewys word op die aspek van politiek en prediking - wat duidelik van politieke prediking onderskei moet word. Prediking uit die profete en profetiese prediking, prediking oor individuele én sosiale vcaagstukke, is 'n onmisbare bestanddeel van die predikant se roeping. Ons het reeds daarna verwys dat Sinode Potchefstroom 1970 hieroor 'n duidelike besluit geneem het.

Omdat prediking oor politiek een van die moeilikste en sensitiefste aspekte van prediking is, is dit begryplik dat hier na 'n ontsnappingsmeganisme gesoek sou word deur die onderskeiding tussen politiek en partypolitiek in te voer. Oor die politiek mag dan gepreek word maar nie oor die partypolitiek nie. Die motivering hiervoor is verstaanbaar - die eenheid en 'stigting' van die gemeente - maar die argument is ondeurdag en ondiep, want dit impliseer dat daar tog maar weer iewers 'n terrein uitgesonder word waaroor die lig van die Woord nie mag val nie, en dis onhoudbaar. Ons preek buitendien ook baie selektief: daar word baie gepreek teen die partypolitiek van die Kommunisme en die SAKP - en waarom sou daar dan nie gepreek mag word oor die beleid of beleidsaspekte van ander partye nie? Weer eens, dit gaan hier nie oor politieke prediking nie maar oor Skrífprediking óór die politiek. Ek het genoem dat dit 'n delikate onderwerp is met vele voetangels en klemme en inderdaad alleen in vrees en bewing en met veel gebed en 'n duidelike roeping aangepak kan word. Die gevaar is immers voortdurend aanwesig dat die predikant sy wil as die wil van God kan verkondig en sy politiek as die politiek van God.

\subsection{Politiek en pastoraat}

Ten derde kan gewys word op die aspek van politiek en pastoraat. Die vraag ontstaan of die predikant alle gesprekke oor politiek tydens huisbesoek naarstiglik moet vermy. Wat moet hy doen indien 'n bekommerde lidmaat hom openhartig oor die politiek uitvra? Wat moet hy doen indien iemand die staatspresident of die leier van die opposi- 
sie openlik belaster? Moet hy tydens huisbesoek net oor die sogenaamde 'geestelike dinge' praat of moet hy 'geestelik oor die dinge' praat, dus ook die politiek? Afgesien daarvan dat hy by blanke gelowiges vir 'n gesindheid van liefde en aanvaarding ten opsigte van mensverhoudings sal pleit, behoort hy ook die aandag daarop te vestig dat daar talle (swart) Gereformeerde lidmate is wat aan die ANC behoort.

In sy pastorale bediening, as 'n veelsydige bediening, sal die predikant as herder met hierdie vrae te doen kry en sal hy dit moeilik kan omseil. Hy moet die kudde, veral die eenvoudiges, sorgsaam lei en sonder bombasme, opdringerigheid en 'n houding van alwetendheid vir hulle die beginsels van die koninkryk vir die politiek uitspel. Die politieke keuse moet egter aan die gelowige self oorgelaat word.

\subsubsection{Politiek en kategese}

Ten vierde kan aandag gevra word vir die faset van politiek en kategese. Die Bybel- en ook kerkgeskiedenis skep ruim geleentheid om die verhouding geloof en politiek met die kinders te behandel, byvoorbeeld wanneer in die Ou Testament die woorde en dade van die profete behandel word. In die kerkgeskiedenis kan gedink word aan die geskiedenis van die stryd tussen die pous en die keiser. Reeds hier kan klem gele word op 'n koninkryksentriese benadering sonder oorskatting of onderskatting van die belang van politiek.

\subsubsection{Politiek en sending}

'n Vyfde faset raak politiek en sending. Die sendingmotief van 'siele wen vir Jesus' het reeds lankal plek gemaak vir 'n meer holistiese benadering waar dit gaan om die redding van die totale mens, ja, van die totale skepping. Sending mag nie psigologies verwater en polities versmal word nie, omdat dit in die evangelie gaan om die volle redding van die volle mens en van die hele skepping, die politiek ingesluit. Politieke sending is (letterlik) heilloos, maar die sosio-politieke dimensie mag in die sending nie ontbreek nie. Saam met die verkondiging van die evangelie van die koninkryk, gaan ook die opheffing van menslike en sosiale lyding (Matt. 10:7-8). Die Bevrydingsteologie het tereg vir die sosiale dimensie van die evangelie aandag gevra maar dit helaas totaal oorspan.

\subsubsection{Politiek en kerkvergaderings}

In die sesde plek kan die vraag gestel word in verband met die verhouding tussen politiek en kerkvergaderings. Dit is bekend dat artikel 30 van die Kerkorde bepaal dat op kerkvergaderings slegs 'kerklike sake' behandel moet word. Minder bekend, of in elk geval minder funksioneel, is artikel 28 wat bepaal dat kerklike vergaderings die plig het om in voorkomende gevalle as kerk van Christus "voor die owerheid te getuig". Sinode 1942 van die GKSA het ook bepaal dat die "geen ander" (as kerklike sake) "nie 
in absolute sin" opgevat moet word nie. Kerkvergaderings het die roeping "om die lig van die Woord van God oor alle lewensfunksies te laat uitstraal" het Sinode 1942 bygevoeg. Predikante vorm 'n deel van die kerkvergaderings en is dus betrokke by die uitstraling van die lig van die Woord en die getuienis voor die owerheid. Nie dat staatkundige kwessies in kerklike samekomste besleg moet nie, maar wel dat kerkvergaderings ' $n$ profeties-kritiese funksie in die samelewing moet vervul. Die kerk mag nie oor die samelewing héérs nie maar moet die samelewing met die Woord van God dién. Om dit op 'n verantwoorde wyse te kan doen, moet predikante op die hoogte wees van die sosio-politieke vraagstukke van die dag.

Daar moet veral gewaak word teen 'n opportunistiese gebruik van die Kerkorde deur byvoorbeeld artikel 30 as uitveebesem te gebruik wanneer dit oor 'n saak gaan wat onsself intens raak, maar dan weer artikel 28 te gebruik om opponente by te kom. So 'n hantering van die Kerkorde is hoogs immoreel.

\subsubsection{Die prediking en publikasies}

In die sewende plek mag die publikasies van die predikant nie vergeet word nie. Deur sy skriftelike getuienis in die gemeente- en kerkblad, in dagblad en teologiese tydskrif kan hy ' $n$ baie groot bydrae lewer tot besinning oor 'n politiek van die koninkryk. Hy kan waarsku teen fanatisme en neutralisme en hy kan pleit vir 'n vreedsame en regverdige samelewing.

\subsubsection{Die predikant se eksistensie}

In die agtste en laaste plek kan daarop gewys word dat die predikant se eksistensie as sodanig al politieke betekenis het. As man van God voer hy 'n voorbeeldige bestaan in die samelewing. Hy is immers draer van 'n boodskap van liefde en nie van haat, van versoening en nie van verwydering, van geregtigheid en nie van onreg, van vrede en nie van geweld, van diens en nie van dominasie nie. Sy eksemplariese bestaan lewer ' $n$ kritiek teen 'n samelewing wat 'n alte onmenslike gelaat vertoon.

\subsection{Politieke betrokkenheid}

Hier kom die vraag na vore of 'n predikant noodwendig aan 'n betrokke politieke party moet behoort en of hy aktief aan partypolitieke bedrywighede moet deelneem. Moet hy bereid wees om die vergadering van enige politieke party met Skriflesing en gebed te open?

Dit is moeilik en waarskynlik ook onwenslik om hierdie vrae so in die algemeen te beantwoord. Baie sal van plaaslike omstandighede afhang. Duidelik is egter dat dit seker nie noodwendig is dat 'n predikant aan 'n bepaalde politieke party sal behoort ten einde polities betrokke te handel nie. In wat reeds genoem is, is geargumenteer 
dat die predikant se bediening 'n politieke dimensie bevat en dat hy hom nie daarvan kan losmaak nie. Terwyl hy hierdie roeping nougeset nakom, moet hy daarteen waak dat hy nie sy bediening in politiek laat opgaan en sy bediening sodoende verpolitiseer nie. Wat die opening van politieke vergaderings betref, moet hy hom telkens deur sy gewete laat lei, in die wete dat al sou hy ook 'n vergadering van 'n party open van wie hy totaal verskil, hy nog altyd die geleentheid het om deur Skriflesing en gebed getuienis af te le van die politiek van die koninkryk.

\section{TEN SLOTTE}

Ten slotte twee opmerkings. Die eerste is dat die huidige onbetrokkenheid van die gemiddelde gereformeerde predikant by die huidige politiek ' $n$ afbuiging is van die reformatoriese benadering na 'n meer piëtistiese siening. In 1916 het 'n Gereformeerde predikant, ds. (later prof.) J.A. du Plessis, in Pretoria 'n lesing gehou oor "Op die spore van die Calvinisme" waarin het hy die volgende stelling gemaak het:

Laat niemand daarom 'n kalvinistiese predikant verdenk als hij tegelijkertijd ook politikus is, omdat hij geroepe is om met die Bijbel, wat hij bedien, ook die wereld in te gaan, en sig nie mag opsluit in 'n predikante-poppe-kas.

Die adagium 'hou die kerk/predikant uit die politiek' is goed bedoel maar mis die waarheid; die vraag is nie of die kerk/predikant by die politiek betrokke sal wees nie maar hóe. Calvyn het kerk en politiek onderskei, maar in die na-Calvynse ontwikkeling is (in navolging van Luther met sy twee-rykeleer) hiervan 'n skeiding gemaak. Die vraag ontstaan waarom ons op hierdie punt van Calvyn wegbeweeg het. Vanweë ideologiese verblinding? Of onkunde ten opsigte van die gereformeerde leer? Of vanweë die vrees vir mense?

Tweedens moet gereformeerde predikante die vermoë ontwikkel om tussen die uiterstes van kwiëtisme en aktivisme deur te stuur. Swye laat die wêreld onveranderd en gee vrye spel aan die sonde; aktivisme is meedoënloos en wetties en laat die mens vergeet dat die verlossing nie vóór ons lê nie maar agter ons.

Politiek, het president Charles de Gaulle by geleentheid opgemerk, is 'n te belangrike saak om net aan politici oorgelaat te word. Inderdaad, politiek het die lig van die evangelie en die begeleiding van almal in die samelewing nodig - predikante ingesluit. 